\title{
Expression of recombinant Streptokinase from local Egyptian Streptococcus sp. SalMarEg
}

\author{
Sobhy AI Sohaimy ${ }^{1}$, Eiman Aleem ${ }^{3 *}$, Elsayed E Hafez ${ }^{2}$, Sally S Esmail ${ }^{1}$, Muhammad El- \\ Saadani ${ }^{4}$ and Nihad Abdel Moneim ${ }^{4}$
}

\author{
${ }^{1}$ Department of Agricultural Industries and Food Technology, \\ ${ }^{2}$ Plant Molecular Pathology Department, Arid Lands Cultivation and Development Research Institute (ALCDRI), City of \\ Scientific Research and Technology Applications (CSAT), Universities and Research Centers District, New Borg Elarab, \\ 21934, Alexandria, Egypt. \\ ${ }^{3}$ Division of Molecular Biology, Zoology Department, \\ ${ }^{4}$ Biochemistry Department, Faculty of Science, Alexandria University, Moharam Bey 21511, Alexandria, Egypt.
}

Accepted 13 May, 2011

\begin{abstract}
Streptokinase (SK) is a therapeutically important thrombolytic agent. Cardiovascular disease is the first cause of adult death worldwide. In Egypt about $13 \%$ of the population die every year due to ischemic heart disease. In spite of this fact, there is no local production of cardiovascular therapeutics. We reported for the first time the expression of a recombinant SK from a local Streptococcus strain. When produced on industrial scale this r-SK may substantially contribute to reducing the costs of thrombolytic therapy in developing countries. In this study, a highly purified r-SK from Streptococcus sp. isolated from Egyptian pharyngitis patients was obtained. The isolated strain was partially identified using 16S rDNA sequencing and named Streptococcus sp. SalMarEg. It was found to be phylogenetically related to Streptococcus pyogenes. Analysis of the obtained sequence showed high similarity with other SK genes. The protein expression in a prokaryotic system obtained a 47-kDa SK protein that could be purified using a single-step his-tagged affinity purification chromatography, with nearly $\mathbf{8 0} \%$ recovery. The clot lytic activities of both recombinant and commercial SK were similar, thus giving the basis to scale up this SK product in order to evaluate the possibilities of its commercialization in local and/or regional markets.
\end{abstract}

Key words: Streptokinase, Streptococcus SalMarEg, thrombolytic agent, heterologous expression.

\section{INTRODUCTION}

Cardiovascular disease is one of the leading causes of death worldwide. According to World Health Organization (WHO) about $13 \%$ of Egyptian population die every year due to ischemic heart disease, which is considered the first cause of adult death in Egypt. Intravenous thrombolysis is the standard therapeutic approach for patients with acute myocardial infarction (Murray et al., 2010). Streptokinase (SK) is a life-saving clot-dissolving drug routinely prescribed universally in the management of

${ }^{\star}$ Corresponding author: E-mail. Eiman.aleem@ki.se.Tel: +46 851775242 . Fax: +46 8321047.

Abbreviations: SK, Streptokinase; r, recombinant. heart attack (Banerjee et al., 2004). It is now the leading fibrinolytic agent in the treatment of thromboembolic conditions (Boersma et al., 2003). It is known that the administration of a thrombolytic agent within six hours of the chest pain onset would reduce the risk of death by $40 \%$.

SK is a protein secreted to the growth medium by many beta-hemolytic Streptococcus strains. SK activates plasma plasminogen to plasmin (Malke and Ferretti, 1984) causing fibrinolysis (Khil et al., 2003; Sun et al., 2004). Two plasminogen activators that occur naturally in the blood are the tissue type (t-PA) and the urokinase type (UPA). Both t-PA and UPA are trypsin-like serine proteases, which activate plasminogen directly (Coleman et al., 2005).

Currently, despite the wide use of tissue plasminogen 
activators in developed countries, SK remains essential to the management of acute myocardial infarction in developing nations (Sikri and Bardia, 2007). In Egypt, there are no specialized biotechnology firms and most pharmaceutical products are imported in bulk and then packaged in the country. Therefore, for socio-economical reasons, local biotechnological production of SK in Egypt would substantially contribute to reducing the costs of this important thrombolytic agent.

Native SK is a single chain polypeptide with a molecular weight of $47 \mathrm{kDa}$. The protein consists of 415 amino acid residues in a single polypeptide chain. Due to the pathogenicity of its natural host, the gene encoding SK has been cloned and expressed in several heterologous hosts such as Escherichia coli (Malke and Ferretti, 1984; Malke et al., 2000; Yazdani and Mukherjee 2002), Bacillus subtilis (Wong et al., 1994), Lactococcus lactis (Sriraman and Jayaraman, 2006), Pichia pastoris (Pratap et al., 2000), and Streptomyces lividans (Kim et al., 2010). On the other hand, hemolytic streptococci secrete several toxins that complicate the downstream purifycation (Pimienta et al., 2007).

Several affinity chromatography methods have been discussed for purifying SK. The earliest of such procedures used insolubilized di-isopropyl fluorophosphates (DIP) plasmin as the affinity ligand (Castellino et al., 1976). Purification through the affinity column caused a $30 \%$ decrease in the streptokinase activity. Different affinity purification methods used a monoclonal antibody ligand (Andreas, 1990; Babashamsi et al., 2009), acylated plasminogen or plasmin as the affinity ligand, or a combination of human plasminogen and monoclonal antibody against SK for chromatographic purification (Rodriguez et al., 1994). This purification method produced a preparation with about 50,000 units of activity per $\mathrm{mg}$ of protein and a purity of $>93 \%$. Since then, highly purified SK has become an important tool in fibrinolytic therapy.

Despite the mentioned advances, the low yield obtained in normal SK production and the pathogenicity of its natural host were the principal reasons leading to the development of a recombinant source. In this study we isolated a streptococcal strain from Egyptian pharyngitis patients and identified it as Streptococcus sp. SalMarEg using 16S rDNA sequencing. We amplified a full coding SK sequence using primers flanking the complete coding sequence of other Streptococcus species and cloned the product in $E$. coli. The recombinant product was then expressed in a prokaryotic expression system and obtained the purified SK protein $(10 \mu \mathrm{g} / \mathrm{ml})$ in a bioactive form with similar activity to commercial SK. To our knowledge, this is the first attempt to produce recombinant SK from local Egyptian species.

\section{MATERIALS AND METHODS}

\section{Bacterial isolation, selection and culture}

Throat swabs of pharyngitis patients were obtained from the Micro- biology Department (Medical Research Institute, Alexandria University), and streaked on blood agar plate (Oxoid Ltd., Hampshire, United Kingdom) with Streptococcus selective media. Single colonies were streaked again on blood agar plates and incubated at $37^{\circ} \mathrm{C}$ overnight in order to estimate its hemolytic activity (agar plate contained 5 to $10 \%$ human blood). $\beta$-Hemolytic activity is associated with complete lysis of red blood cells. The colony with the highest hemolytic activity was inoculated in $5 \mathrm{ml}$ of LB broth and incubated overnight at $37^{\circ} \mathrm{C}$. The culture was subsequently inoculated into $50 \mathrm{ml}$ of LB broth.

\section{Identification of the Streptococcus sp. SalMarEg}

Bacterial genomic DNA was extracted from an overnight bacterial culture using QIAGEN DNA extraction kit according to the manufacturer's protocol. The 16S rDNA was amplified from the bacterial genomic DNA using a 16S rDNA universal primer pair: 1155F: 5'-AAC TGG AGG AAG GTG GGG AT-3' (gb| HQ658085.1) R: 5'-AGG AGG TGA TCC AAC CGC A-3' according to Innis et al. (1990). PCR was performed in a total volume of $50 \mu$ l containing 5 $\mu \mathrm{l}$ of $5 \times$ Green Go Taq flexi buffer (Promega, USA ), $5 \mu \mathrm{l}$ of $5 \times$ colorless Go Taq flexi buffer (Promega, USA), $5 \mu \mathrm{l} \mathrm{MgCl} 2(25 \mathrm{mM})$ (Promega, USA), $2 \mu \mathrm{l}$ of dNTP mixture (10 mM of each) (BIORON, Germany), $50 \mathrm{ng}$ bacterial genomic DNA as template, $4 \mu \mathrm{l}$ of each primer $(20 \mathrm{pmol} / \mu \mathrm{l})$ and $2 \mathrm{U}$ Taq polymerase $(5 \mathrm{U} / \mu \mathrm{l})$ (Promega, USA). The volume was completed to $50 \mu \mathrm{l}$ with sterile $\mathrm{ddH}_{2} \mathrm{O}$. The PCR thermal profile used to amplify $16 \mathrm{~S}$ rDNA was as follows: initial denaturation step at $95^{\circ} \mathrm{C}$ for $3 \mathrm{~min}$, followed by 35 cycles of amplification with denaturation at $95^{\circ} \mathrm{C}$ for $1 \mathrm{~min}$, annealing at $55^{\circ} \mathrm{C}$ for $1 \mathrm{~min}$ and extension at $72^{\circ} \mathrm{C}$ for $1 \mathrm{~min}$ ending with extension at $72^{\circ} \mathrm{C}$ for $10 \mathrm{~min}$. PCR amplification was performed using a thermocycler (MJ Research, model PTC-200 Peltier, USA). Purification of the amplified 16S rDNA fragment was performed using QIAquick PCR purification kit according to manufacturer's instructions. Sequencing of the $16 \mathrm{~S}$ fragment was carried out by MACROGEN, Korea using the 16S rDNA forward primer. Alignment of 16S rDNA sequence was conducted using CLUSTAL W (1.83) multiple sequence alignment software (Thompson et al., 1994; Larkin et al., 2007). Phylogenetic tree and molecular evolutionary analyses were performed according to NCBI nucleotide BLAST, genbank database and generated by CLC Genomics workbench-3.

\section{Amplification, cloning and sequencing of the SK gene}

A specific SK primer pair flanking the complete coding sequence was designed using DNA star software from about 218 DNA sequences representing genes from different streptokinase species selected from GenBank: 1F 5'-TAC TAA CGA CCT GGA CTC AC 3' and 1248R 5'-TAT TGG GAT TGC TG TTT ATT-3' (Streptococcus dysgalactiae subsp. equisimilis strain 04/04 streptokinase gene, complete coding sequence (gb| HQ629621.1). Gene amplification was carried out using standard PCR as described above, however with annealing temperature of $51^{\circ} \mathrm{C}$. The amplified PCR product was purified using the EzWay ${ }^{\mathrm{TM}} \mathrm{Gel}$ Extraction kit according to the manufacturer's protocol then cloned into pCR $^{\circledR} 2.1$ TOPO $^{\circledR}$ cloning vector in Top $10 \mathrm{E}$. coli strain using TOPO TA Cloning $\mathrm{Kit}^{\circledR}{ }^{\circledR}$ (Invitrogen ${ }^{\mathrm{TM}}$, USA). The insert was verified by DNA sequencing (MACROGEN, Korea) using the following forward primer 442F 5'-GGT TTA GTT CAT GTA TCG-3'.

\section{Expression of SK gene}

The cloned SK gene was released from the $\mathrm{PCR} \circledast 2$ 2.1-TOPO® vector using EcoRI restriction enzyme, and purified using EzWay ${ }^{\mathrm{TM}}$ Gel Extraction kit (KOMBIOTECH, Korea) and ligated to 
the linearized prokaryotic expression vector pPROEX ${ }^{T M}$ HT according to the manufacturer's protocol. The pPROEX ${ }^{T M}$ HT Prokaryotic Expression System was designed for expression of foreign proteins fused to a $6 \times$ histidine sequence (His) 6 for affinity purification (Life Technologies, Inc. by QIAGEN, Inc., USA) (Hoffman and Roeder, 1991). E. coli strain $\mathrm{DH}_{5} \alpha$ competent cells were used in this study for subcloning of $r$-SK. Expression of $r$-SK was induced using Isopropyl- $\beta$-D-1-thiogalactopyranoside (IPTG) as follows: a single colony of sub-cloning transformation reaction was inoculated into $2 \mathrm{ml}$ of LB media containing $100 \mu \mathrm{g} / \mathrm{ml}$ ampicilin. The culture was incubated overnight at $37^{\circ} \mathrm{C} .10 \mathrm{ml}$ of LB media containing $100 \mu \mathrm{g} / \mathrm{ml}$ ampicilin were inoculated with $0.1 \mathrm{ml}$ of overnight culture and allowed to grow at $37^{\circ} \mathrm{C}$. When the culture reached an $A_{590}$ of 0.5 to $1.0,1 \mathrm{ml}$ was removed and centrifuged for $1 \mathrm{~min}$ in a microcentrifuge (Hittich MIKRO 20, Germany). The supernatant was discarded and pellets resuspended in $100 \mu \mathrm{l}$ of PBS and designated as (the uninduced sample). The remaining culture was induced by addition of IPTG to a final concentration of $0.6 \mathrm{mM}$ and incubated as mentioned before. $1 \mathrm{ml}$ culture was removed after $1,2,3 \mathrm{~h}$ after induction and $\mathrm{OD}$ measured at $A_{590}$. The cells were centrifuged as described above and the pellets resuspended in $100 \mu \mathrm{l}$ of PBS and designated (the induced sample). $20 \mu \mathrm{l}$ of each induced and non induced samples were mixed with an equal volume of $2 X$ SDS sample buffer, boiled and were analyzed by SDS-polyacrylamide gel electrophoresis.

\section{Affinity purification of $6 \mathrm{X}$ Histidine-tagged r-SK}

The expressed $r$-SK fused to $6 x$ His residue has a strong affinity against Ni-NTA resin matrix (QIAGEN, Inc., USA) (Hoffman and Roeder, 1991) that specifically binds His-tagged proteins. The induced bacterial cells were collected and resuspended in 4 volumes of lysis buffer [50 mM Tris- $\mathrm{HCl}\left(\mathrm{pH} 8.5\right.$ at $\left.4^{\circ} \mathrm{C}\right), 100 \mathrm{mM}$ $\mathrm{KCl}, 5 \mathrm{mM} \beta$-mercaptoethanol, $1 \mathrm{mM}$ PMSF]. The suspension was lysed by sonication, the cell debris removed by centrifugation and the supernatant transferred to a fresh tube (crude supernatant). Affinity purification was performed according to the manufacturer's protocols (QIAGEN NI-NTA affinity purification kit). The column was equilibrated with column binding buffer. The crude sample was loaded onto the column, which was washed with 10 volumes of binding buffer, then 2 volumes of wash buffer, followed by 2 volumes of binding buffer. The bound proteins were eluted with elution buffer (Life Technologies, Inc. by QIAGEN, Inc., USA).

\section{Determination of r-SK concentration}

Protein concentration was estimated in the elution fraction by Bradford assay. A standard curve was made using bovine serum albumin (BSA) with different concentrations $(0,2.5,5,7.5,10,12.5$, $15,17.5$ and $20 \mu \mathrm{g} / \mathrm{ml}) .40 \mu \mathrm{l}$ of dye stock were mixed with $160 \mu \mathrm{l}$ of protein standard solution or samples to be assayed and incubated for $10 \mathrm{~min}$. Absorbance was then measured at $595 \mathrm{~nm}$ in a spectrophotometer (Perkin Eimer, lambda EZ 20l, USA). The total protein content of purified r-SK was calculated from the standard curve (Bradford, 1976).

\section{Solubilization and renaturation of r-SK inclusion bodies}

In this study, r-SK was expressed as insoluble inclusion bodies (inactive form), which required renaturation as follows: the inclusion pellets were solubilized in $8 \mathrm{M}$ urea buffer at $\mathrm{pH} 8$. The mixture was incubated at $25^{\circ} \mathrm{C}$ for $1 \mathrm{~h}$ before the insoluble parts were removed by centrifugation. The solution was then diluted with phosphate buffer $(\mathrm{pH} \mathrm{10.7)}$ for SK renaturation. The solution was transferred for dialysis against the buffer $[20 \mathrm{mM}$ Tris/ $\mathrm{HCl}$ pH 8.0, $50 \mathrm{mM} \mathrm{NaCl}$,
$1 \mathrm{mM} \mathrm{EDTA}]$ at $4^{\circ} \mathrm{C}$ overnight. The folded SK was then assayed as thrombolytic agent. Using this procedure, approximately $3.0 \mathrm{mg}$ of enzymatically active SK was obtained from $1 \mathrm{~g}$ wet weight.

\section{Gel electrophoresis and Western blotting}

Protein samples were prepared and run on $12 \%$ SDS-polyacrylamide gel in the presence of pre-stained molecular weight markers (14 to $116.0 \mathrm{kDa}$ ) (Jena Bioscience, Germany). Proteins were then transferred to a nitrocellulose membrane (Costa, Bio Blot, Canada) for $1 \mathrm{~h}$ at $0.3 \mathrm{~A}$, and detection was performed using BCIP/NBT liquid Substrate System (Sigma, USA).

\section{Enzyme activity assays}

\section{Zymography}

Samples were run on $12 \%$ of PAGE with PBS but water in the separating gel was replaced by human plasma diluted (1:5). After running, the gel was soaked in $1 \%$ Triton $X 100$ for $2 \mathrm{~h}$. The solution was changed every $1 \mathrm{~h}$ to remove SDS for renaturation of the enzyme. The gel was then washed three times with tap water and soaked in universal buffer $\mathrm{pH} 8$ for $2 \mathrm{~h}$ at $37^{\circ} \mathrm{C}$. The gel was then stained with Coomassie blue stain overnight $(0.25 \%, w / v)$ in methanol-acetic acid-water 5:1:4 (v/v/v) followed by destaining (Laemmli, 1970).

\section{Quantitative assay for determination of r-SK activity}

R-SK activity was estimated as units/mg using a simple quantitative colorimetric method. A standard curve was made using commercial SK with different known concentrations diluted from a stock of (1 $\mathrm{mg} / \mathrm{ml})$ as follows: $(1: 1,1: 2,1: 3,1: 4,1: 5,1: 6$, and 1:7). The principle of the assay is based on the release of Coomassie brilliant blue R-250 dye from the clot on applying SK as thrombolytic agent. $30 \mu \mathrm{l}$ of freshly prepared Coomassie brilliant blue R-250 $(1 \mathrm{mg} / \mathrm{ml})$ was added to $200 \mu \mathrm{l}$ of the diluted human plasma $(1: 5, \mathrm{v} / \mathrm{v})$ and mixed. $100 \mu \mathrm{l}$ of thrombin (Sigma, USA) (2.5 units $/ \mathrm{ml}$ ) were then added to facilitate the formation of a plasma clot. Subsequently, 1 $\mathrm{ml}$ of commercial SK standard (Sigma, USA) $(0.1 \mathrm{mg} / \mathrm{ml})$ was used as a plasminogen activator to initiate clot lysis. The mixture was incubated for $10 \mathrm{~min}$ at $37^{\circ} \mathrm{C}$. During the course of lysis, $100 \mu \mathrm{l}$ of soluble material were transferred to microtiter wells and the absorbance at $540 \mathrm{~nm}$ was determined as a measure of clot lysis as shown in Supplementary Figure 1 (Mao and Tucci, 1991).

\section{Comparison of clot lysis activity of commercial and r-SK}

Venous blood was drawn from 20 healthy people without a history of oral contraceptive or anticoagulant therapy. About $500 \mu \mathrm{l}$ of blood were transferred to previously weighed Eppendorf tubes arranged in two groups: one group for r-SK and the other for commercial SK and incubated at $37^{\circ} \mathrm{C}$ for $45 \mathrm{~min}$. After clot formation, serum was completely removed and each tube was again weighed to determine the clot weight (clot weight= weight of clot containing tube - weight of the tube alone). $100 \mu \mathrm{l}$ of $\mathrm{r}$-SK along with various dilutions in sterile distilled water were added to the tubes $(0.010$, $0.008,0.006,0.004,0.002 \mathrm{~g} / \mathrm{ml})(\mathrm{n}=20$ for each dilution). Water was also added to the other pre-weighted tubes containing clots to serve as negative thrombolytic control. The same dilutions were done with commercial SK group as positive control in order to assess the effectiveness of both SKs as thrombolytic agents. All the tubes were then incubated at $37^{\circ} \mathrm{C}$ for $90 \mathrm{~min}$ and observed for clot lysis. After incubation, the fluid obtained was removed and tubes were 


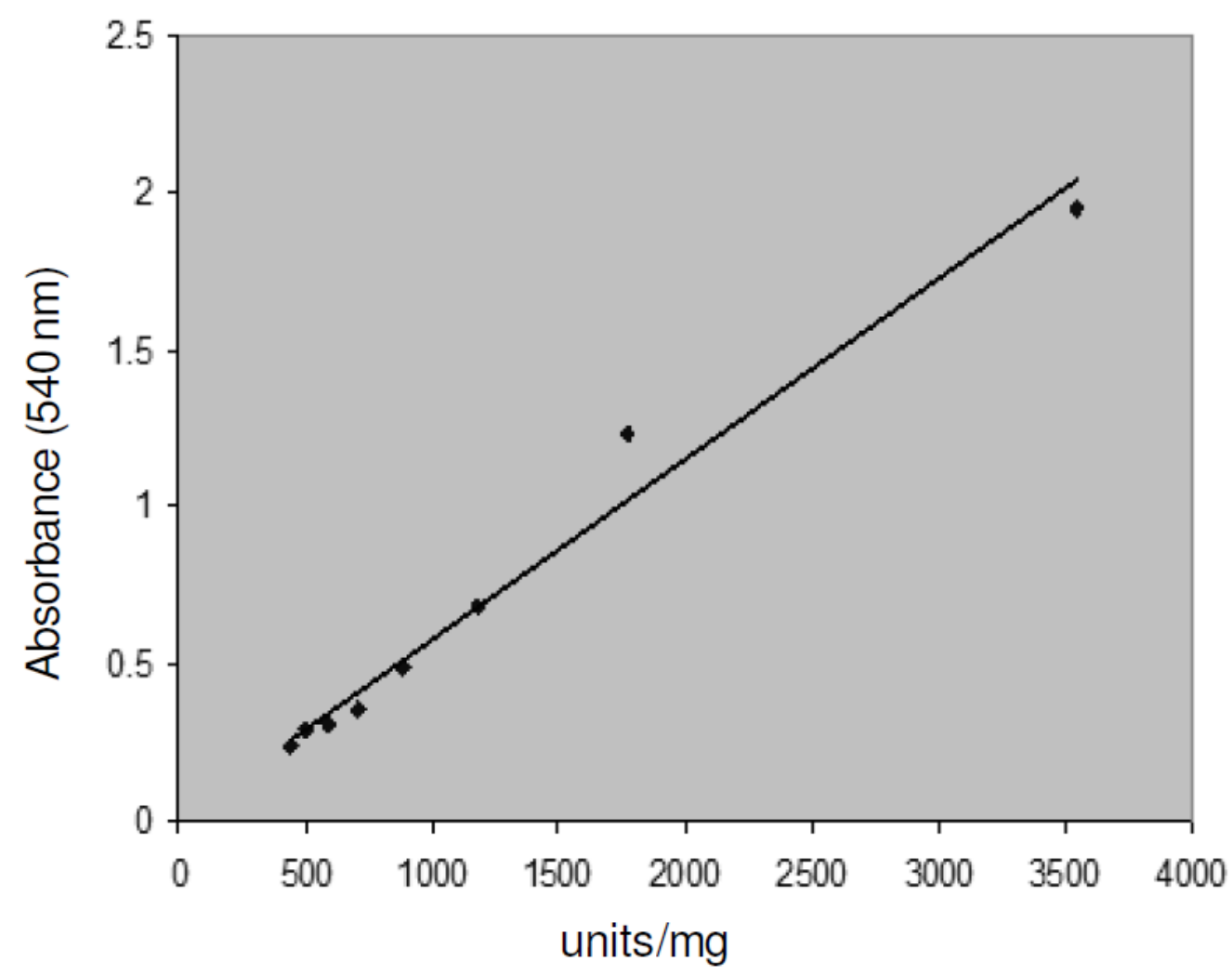

Figure 1. Quantitative colorimetric assay for determination of $r$-SK activity. A standard curve was made using commercial SK with different known concentrations diluted from a stock of $1 \mathrm{mg} / \mathrm{ml}$. These were $3550,1775,1183,887,710,591$ and 444 units/mg, respectively. X-axis represents streptokinase (units/mg) dissolved in $1 \mathrm{ml}$ buffer and $\mathrm{y}$ - axis represents the absorbance at $540 \mathrm{~nm}$.

again weighed. Difference obtained in weight taken before and after clot lysis was expressed as mean percentage of clot lysis. The test was repeated three times for each dilution of $r$-SK and commercial SK in the blood samples of the 20 different healthy people (Prasad et al., 2006).

\section{Ethical approval}

Informed consent from pharyngitis patients and healthy volunteers were collected and approved by the ethics committee of the medical research institute, Alexandria University, Egypt and, therefore the study was performed in accordance with the ethical standards laid down in the 1964 Declaration of Helsinki and its later amendments.

\section{RESULTS}

\section{Isolation and identification of Streptococcus sp.}

We isolated local Streptococcus species using swabs from Egyptian pharyngitis patients, which were routinely streaked on blood agar plates. Out of the swabs from five pharyngitis patients, we isolated Streptococcus $s p$. from one culture containing about 26 colonies of high $\beta$ - hemolytic activity. The isolate with the highest $\beta$-hemolytic activity was selected and its genomic DNA was extracted for molecular taxonomy purposes by amplification and partial sequencing of the 16S rDNA gene (ca $350 \mathrm{bp}$ ) using PCR. Sequence analysis revealed that the selected isolate belongs to the Streptococcus genus and the partial sequence was submitted to GenBank under the accession No. FJ490631. Nucleotide BLAST and phylogenetic analysis of the submitted sequence revealed that it may be a new Streptococcus isolate, and it was subsequently called Streptococcus sp. SalMarEg. Streptococcus sp. SalMarEg had $99 \%$ identity with Streptococcus pneumoniae, Streptococcus intermedius, Streptococcus sanguinis, Streptococcus anginosus and 98\% identity with Streptococcus mitis and Streptococcus suis.

\section{SK gene amplification, cloning and subcloning into prokaryotic expression vector}

The SK gene was amplified from the genomic DNA of Streptococcus sp. SalMarEg using specific SK primers flanking the complete coding sequence of other Streptococcus sp. (Figure 2A, Lane 2). The PCR product $(1000-1500 \mathrm{bp})$ was excised from the gel, purified 

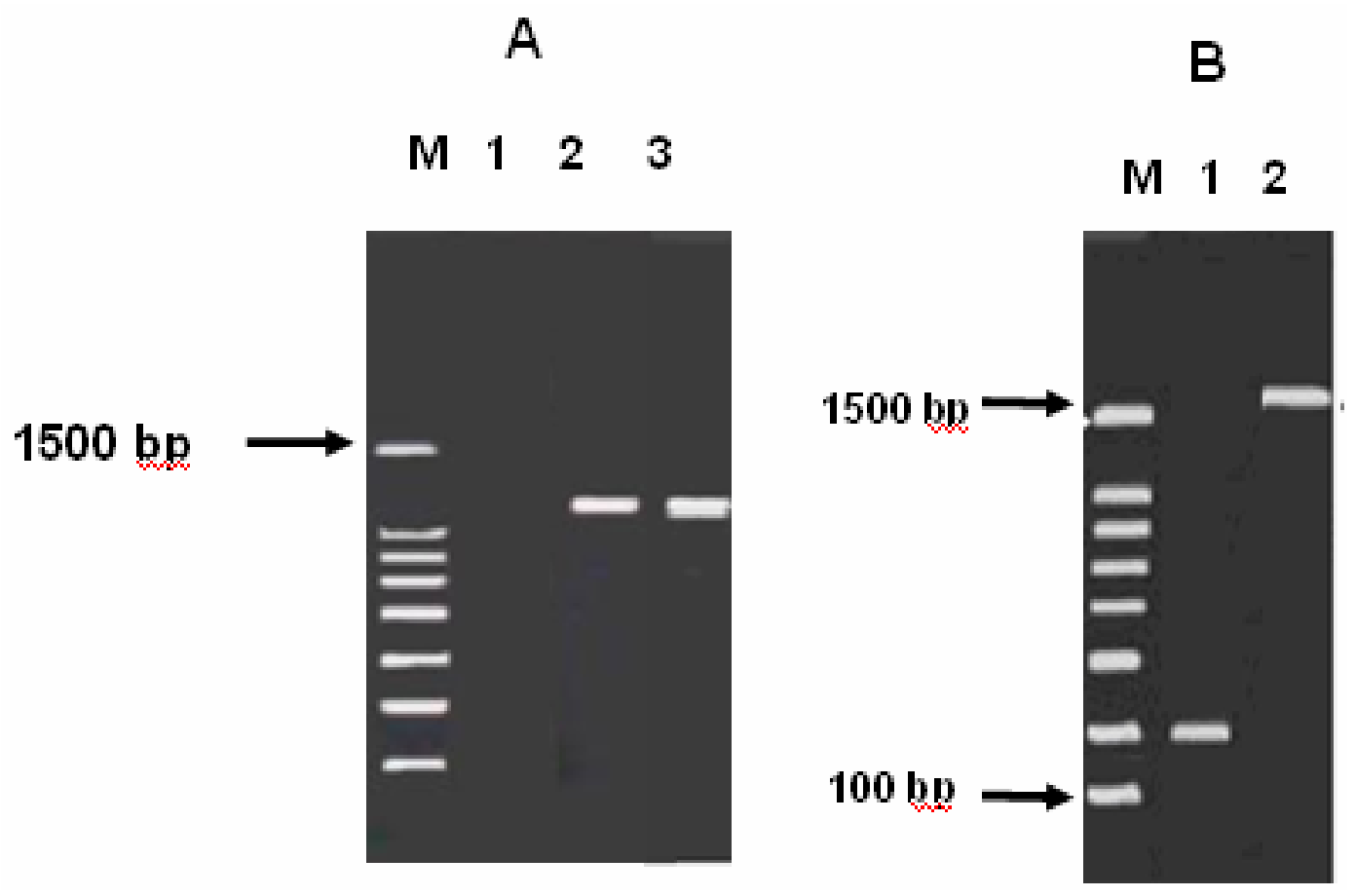

Figure 2. Cloning of SK gene from Streptococcus sp. SalMarEg. One percent agarose gel showing (A) lane M, DNA ladder marker (100 bp) (Biron, Germany); Lane 1, negative control of PCR reaction (contains water); lane 2, PCR amplification product of SK gene ( 1320 bp) from the genomic DNA of Streptococcus sp. SalMarEg.; lane 3, SK insert amplified from TOPO cloning vector using SK specific primers after cloning the SK PCR product. (B) PCR product amplified from TOPO cloning vector using M13 primers. Lane M, DNA ladder marker (100 bp) (Biron, Germany); lane 1, PCR amplification of TOPO cloning vector containing no SK insert; lane 2, PCR amplification of TOPO cloning vector containing SK insert.

and cloned in the pCR 2.1-TOPO plasmid vector. We screened for the SK insert using streptokinase-specific primers, which yielded the expected 1320 bp band (Figure 2A, lane 3), as well as with M13 universal primers, which yielded a $1520 \mathrm{bp}$ band that included an additional $200 \mathrm{bp}$ representing the M13 vector sequence (Figure 2B, Lane 1). Next, we digested the plasmid DNA with $E c o R l$ to release the insert, which was sub-cloned into the prokaryotic expression vector pPROEX ${ }^{\text {TM }} \mathrm{HT}$. The transformed bacterium was subjected to gene induction using IPTG in the culture medium.

\section{Sequencing of the recombinant SK and phylogenetic analysis}

In order to confirm our results, we sequenced the r-SK using SK forward primers and submitted the obtained partial sequence into GenBank database under the accession No. FJ490630. We translated the r-SK nucleotide sequence using ExPASY tool (Albar et al., 2007) and compared its amino acid sequence with that of SK from Streptococcus equisimilis, Streptococcus uberis and Streptococcus pyogenes using CLUSTAL W (1.83) multiple sequence alignment software and Mega4 software (Tamura et al., 2007). The identity scores were $82,25.6$ and $90 \%$ in the aligned regions, respectively (Figure 3). We then used NCBI-BLAST for nucleotide sequence alignment and used the results to construct a phylogenetic tree using CLC Genomics Workbench-3 software (Figure 4).

\section{Purification of r-SK and Western blot analysis}

pPROEX ${ }^{\mathrm{TM}} \mathrm{HT}$ expression vector expresses recombinant proteins fused with $6 x$ His residues. His-tagged recombinant proteins have a great affinity towards $\mathrm{Ni}$ NTA matrix. In this study, the high affinity concen-tration of the recombinant protein enabled single-step purification by one step His-tagged affinity purification chromatography, with nearly $80 \%$ recovery. For the assessment of r-SK purity, washing and elution fractions were examined using 12\% SDS-PAGE (Figure 5A). All samples to be examined were pre-heated prior to running on gel, and about $30 \mu \mathrm{l}$ of each sample were loaded. The purified r-SK-6-His-Tag was then immunoblotted and detected using anti-His-Tag antibody, which gave a 47 


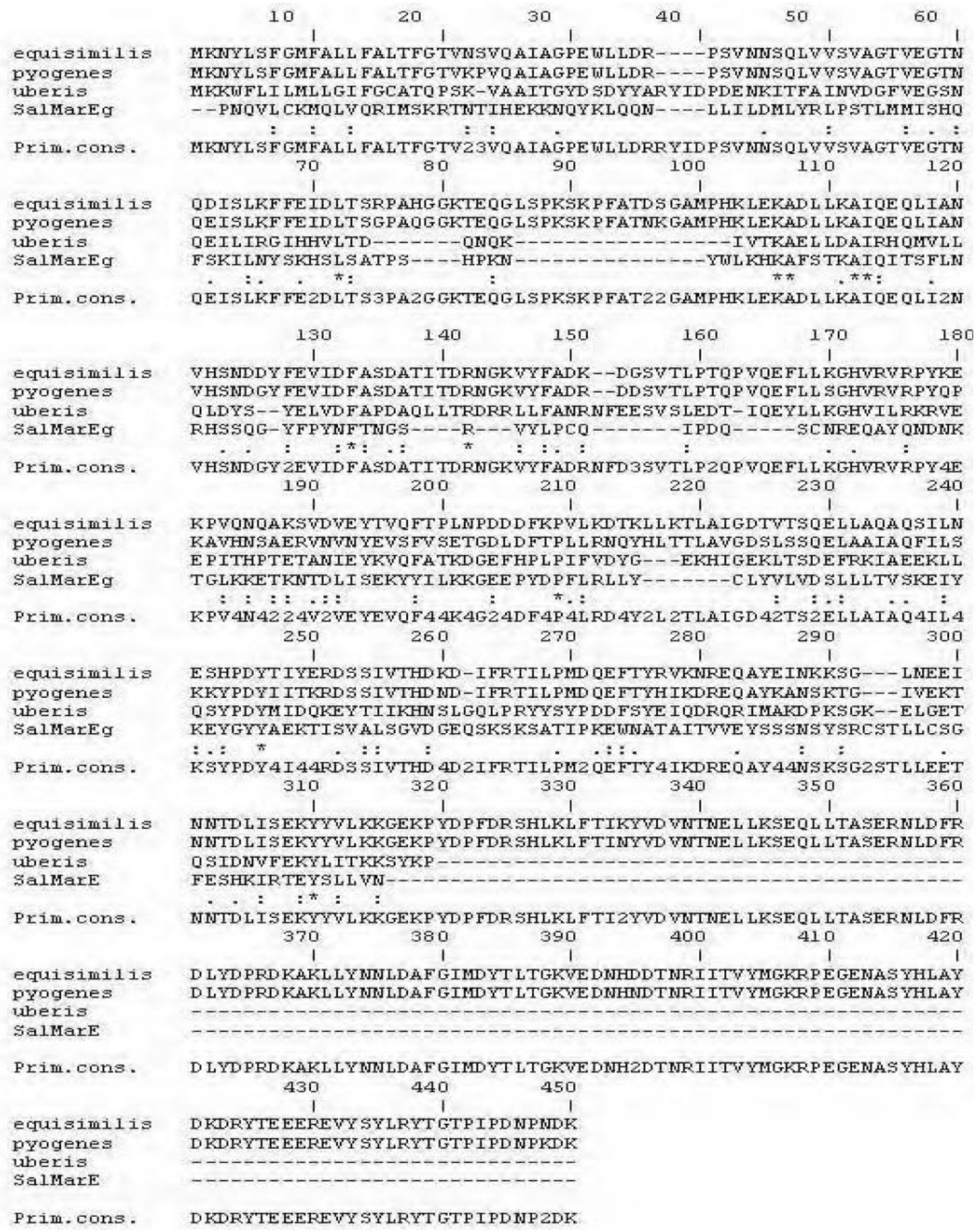

Figure 3. Comparison of the amino acid sequence of r-SK from Streptococcus sp. SalMarEg. to that of SK from S. equisimilis, S. uberis and $S$. pyogenes using CLUSTAL W (1.83) multiple sequence alignment software and Mega4 software (Tamura et al., 2007). The identity (*): 10 is $2.22 \%$, strongly similar; (:): 47 is $10.44 \%$, weakly similar; (.): 28 is $6.22 \%$ and different: 365 is $81.11 \%$. 


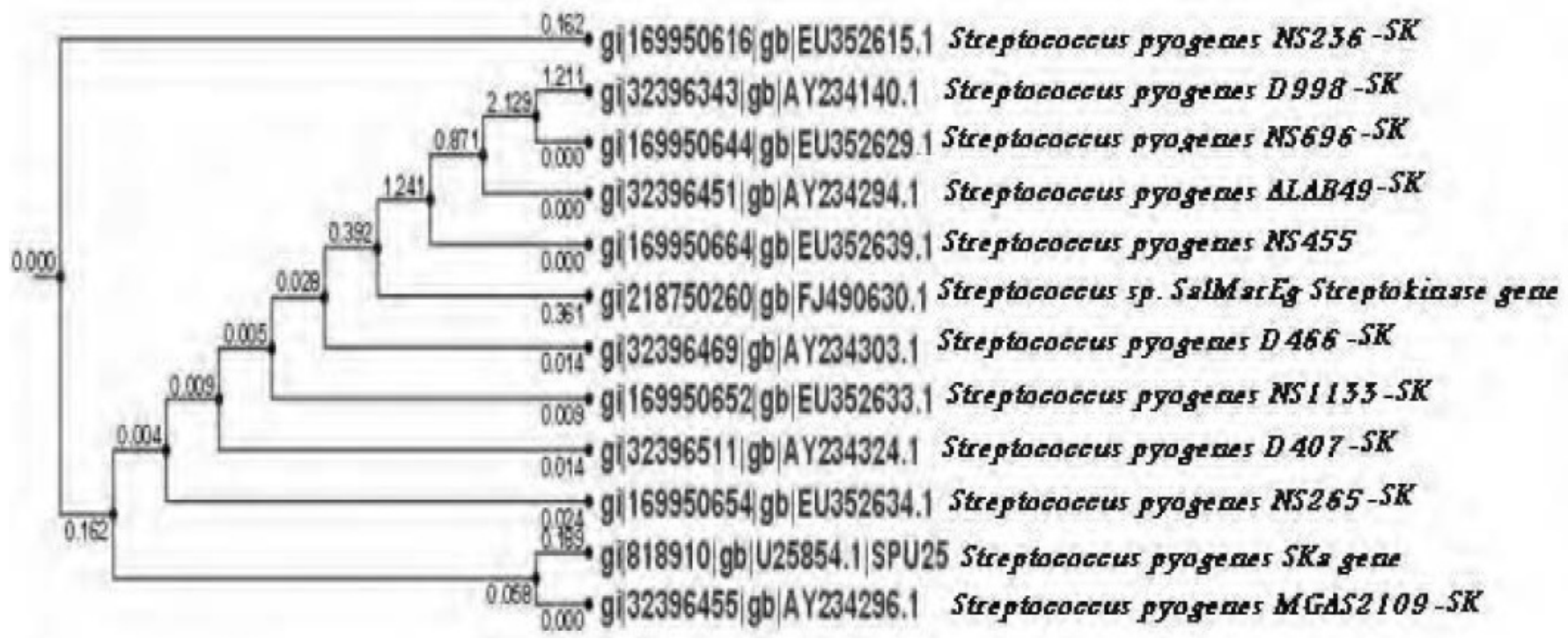

Figure 4. Phylogenetic tree of Streptococcus sp. SalMarEg SK gene partial codons generated by CLC Genomics workbench-3 according to NCBI nucleotide BLAST and GenBank database.

kDa band (Figure 5B).

\section{Detection of r-SK activity}

\section{Zymography}

The renaturation efficiency of $r$-SK was evaluated using zymography. A SK substrate (plasminogen) replaced water in the separating gel in SDS-PAGE. Different concentrations of $\mathrm{r}$-SK were loaded onto the gel and different activities were obtained as shown in Figure 6A.

\section{Colorimetric assay}

A colorimetric assay for SK activity quantification was performed in order to estimate the units $(U)$ of enzyme per $\mathrm{mg}$ of recombinant protein. According to the standard curve from serial dilutions of a commercial SK stock, results revealed that $1 \mathrm{mg} \mathrm{r}$-SK contained about $2950 \mathrm{U}$ (Figure 1).

Comparison of clot lysis activity of r-SK and commercial SK according to the in vitro model study

To determine the in vitro activity of $r$-SK to lyse blood clots, five different concentrations of r-SK $(0.01,0.008$, $0.006,0.004$ and $0.002 \mathrm{~g} / \mathrm{ml}$ ) for each of the 20 blood samples were used. Each experiment was repeated three times. Mean percentage of clot lysis was calculated for each concentration: these were 72.6, 64.2, 62.9, 59.2, $56.7 \%$ for the five different r-SK dilutions, respectively, and $2.2 \%$ for the negative control (water). These results were almost similar to those of the commercial SK (Figure 6B). It was observed that $2000 \mathrm{U} / \mathrm{ml}$ of the commercial native SK gave the same activity as 1904 $\mathrm{U} / \mathrm{ml}$ of the r-SK herein reported.

\section{DISCUSSION}

\section{Isolation and identification of Streptococcus sp.}

In this study, SK isolated from local Streptococcus sp. SalMarEg was efficiently produced in a recombinant bioactive form. It is worthy to mention that the binding of plasminogen by pathogenic Group C streptococci isolated from human, horses, and pigs is specific to the homologous host (McCoy et al., 1991). For this reason, we isolated Streptococcus sp. from human origin. It has been previously reported that SK activity associated with the plasminogen activator secreted from $S$. uberis is different from that of $S$. pyogenes (Lancefield group A) and $S$. equisimilis (Lancefield group $C$ ) strains, as it is able to activate bovine but not human plasminogen. It also differs from that produced by Lancefield group $E$ strains because of its inactivity against porcine plasminogen (Ward and Leigh, 2004).

The isolated Streptococcus strain in this study was molecularly identified based on 16S rDNA gene sequence. In this work, the amplified SK gene from the selected isolate's genomic DNA was cloned into an expression vector. Previous attempts were made to clone SK gene included in vitro cloning by PCR using specific SK primers and restriction digestion of the gene from the whole genome (Malke and Ferretti, 1984). In this study, 

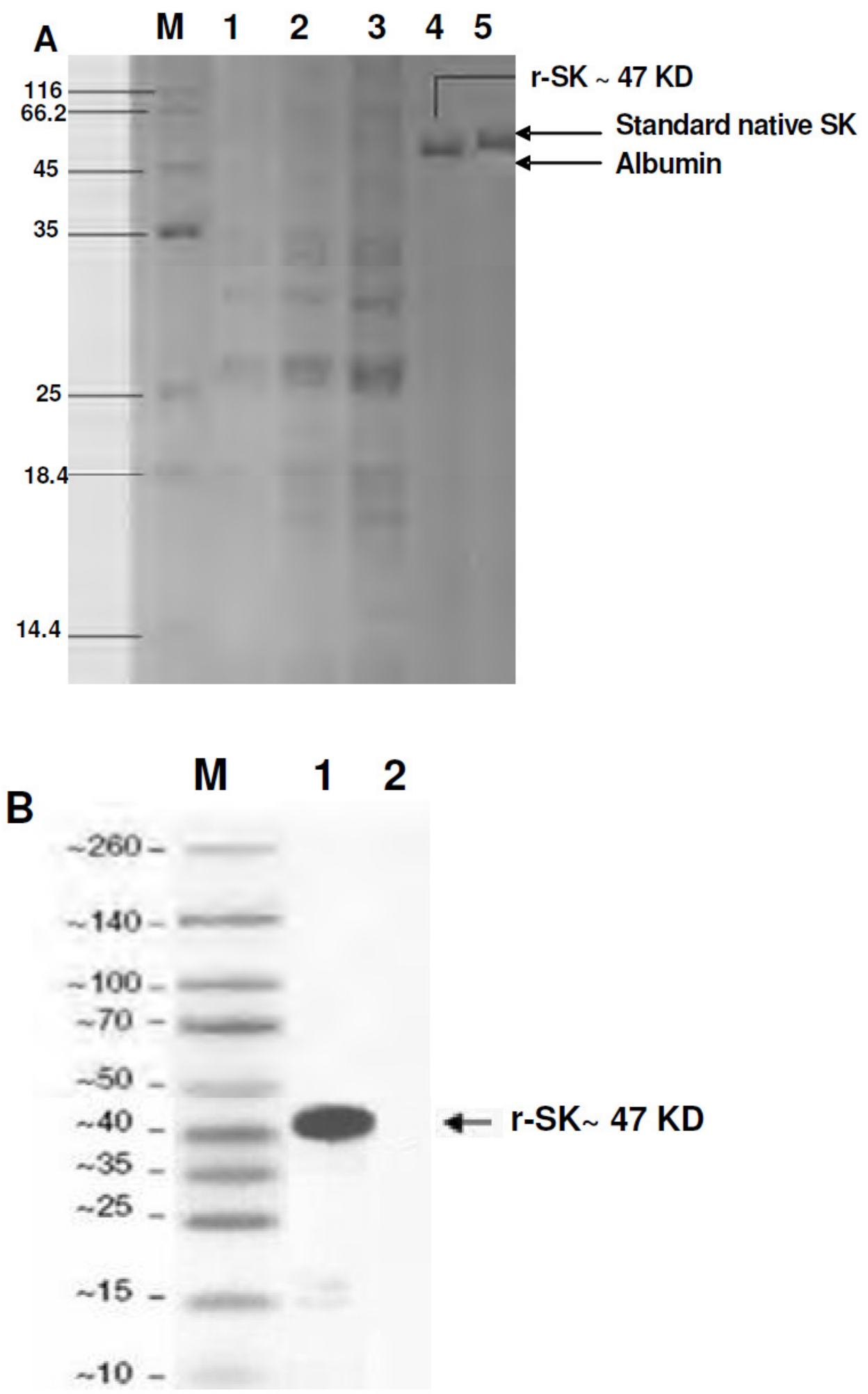

Figure 5. Affinity purification of $r$-SK. (A) $12 \%$ SDS-PAGE showing affinity purification fractions of r-SK.; Lane M, protein molecular weight marker 14.4 to $116 \mathrm{kD}$; Lane 1, uninduced E. coli; Lane 2, IPTG-induced E. coli for r-SK expression; Lane 3, washing fraction of affinity purification; Lane 4, elution fraction ( $r-S K$ ); lane 5, standard native SK (Sigma, USA). (B) Western blot analysis of purified r-SK. Lane M; Spectra ${ }^{\mathrm{TM}}$ Multicolor Broad Range Protein Ladder (10-260 kD) (Fermentas, Canada); Lane 1, r-SK purified fraction detected by QIA Express anti His-Tag detection system (ALP labeled); Lane 2, negative control. 

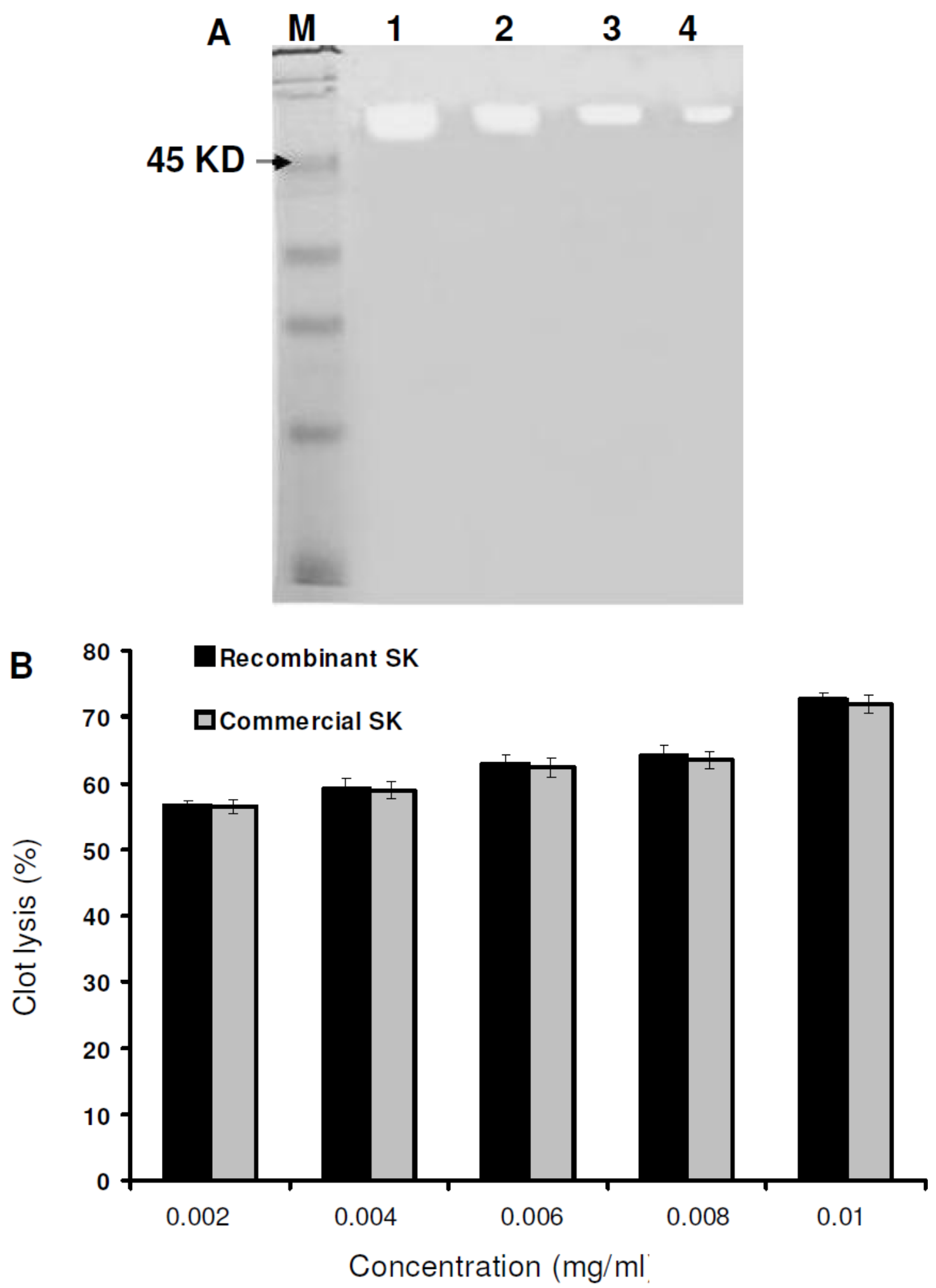

Figure 6. r-SK activity. (A) r-SK activity by zymography. Different concentrations of $r$-SK were run on $12 \%$ SDS-PAGE in 1X electrophoresis buffer, stained with coomassie blue R-250 (Alliance bio, USA) and photographed. Lane M, protein molecular weight marker 14.4 to116 KD (Jena Bioscience, Germany); lane 1, 2 , 3 and 4 each represents $50,40,30$, and $20 \mu \mathrm{l}$ from $0.1 \mathrm{mg} / \mathrm{ml}$ of renatured r-SK. (B) Clot lytic activity of rSK. histogram showing mean \pm SD of clot lytic activities of different concentrations of $r$-SK in comparison to the same concentrations of commercial standard SK (Sigma, USA) using blood samples from normal subjects $(n=20)$. SK activity represents the average of three replicates. 
the r-SK protein (fused with 6X His-Tag) expression was induced by IPTG and the obtained r-SK was subsequently purified. In general, two different strategies for the production of enzymatically active SK were reported. In the first strategy, SK is expressed as inclusion bodies without its signal sequence followed by purification, solubilization, and renaturation to obtain an active preparation. In the second strategy, enzymatically-active SK is secreted into the culture medium. The design of the expression strategy depended on process economics, regulatory requirements and the end-use of the purified protein (such as biochemical studies, structural characterization, and commercial usage as an industrial enzyme). In this study, we used the second strategy as it supports the biochemical characterization and semiindustrial approach for the production of r-SK in Egypt.

\section{Sequencing of the recombinant streptokinase and phylogenetic analysis}

Among the currently known SKs, S. uberis seems to be the least conserved, since the degrees of identity at the nucleotide level for six other streptokinases from serological Groups A, C, and G range between 80 and 98\% (Frank et al., 1995). In line with this observation, no similarity between SK from Streptococcus sp. SalMarEg and SK from S. uberis was found at the nucleotide level by BLAST searching.

The fact that streptococci with different host specificities produce SK that shows considerable sequence diversity but conserved plasminogen activation potential indicates that generation of plasmin activity is important for the pathogenesis of these bacteria. On the other hand, the high degree of amino acid sequence diversity also indicates that only a low degree of sequence constraint is needed for the ability of SK to activate plasminogen. In this study, we used E.coli DH5a strains for the high level expression of r-SK. Mahmoudi et al. (2010) used E.coli BL21 (DE3) plysS strain, which is deficient in cytoplasmic protease gene products and, therefore, gives high level expression of fusion proteins (Sugimura and Higashi, 1988). Other hosts have certain limitations. For example, B. subtilis produces a number of extracellular proteases, which recognize and degrade heterologous proteins. In addition the recombinant vector is largely unstable inside the competent Bacillus strain.

\section{Purification and activity of r-SK}

The possibility to obtain high concentrations of the r-SK enabled the single-step purification by His-tagged affinity purification chromatography, with nearly $80 \%$ recovery. To our knowledge, this would be the first report on a highly pure r-SK in a single-step purification process. Zhang et al. (1999) obtained 49\% recovery and 99\% purity of r-SK using two-step purification by ion exchange followed by gel filtration chromatography. Ignatova et al. (2000) reported purification of excretory r-SK with $51 \%$ recovery and about $97.8 \%$ purity.

Several affinity chromatography methods have been discussed for purifying SK (Castellino et al., 1976; Liu et al., 2000). It was concluded that downstream processing costs can be considerably reduced and yields of pure recombinant protein is enhanced by reducing the number of processing steps and increasing the recovery of protein product in each step. Inclusion bodies, refolding and single-step purification achieves this goal. The whole process of expression and purification involves a minimal set of procedures and is very useful for economic production of proteins with therapeutic significance such as SK on a large scale.

In this study, r-SK was induced as inclusion bodies in a small scale. $10 \mu \mathrm{g} / \mathrm{ml}$ was obtained. Expression of $\mathrm{r}$-SK as inclusion bodies provides a large quantity of the enzyme that can be easily recovered and refolded (Azuaga et al., 2002; Balagurunathan et al., 2008). The production of recombinant protein as insoluble inclusion bodies accumulates about $25 \%$ of total cell protein compared to the soluble secretory recombinant protein, which accumulates up to $15 \%$ of total cell protein (Perez et al., 1998).

In this work, we found that $1 \mathrm{mg} \mathrm{r}$-SK contained about 2950 U. Other studies reported that when r-SK was expressed as secreted into the medium or under shakeflask cultivation method, about 8 to $100 \mathrm{U} / \mathrm{ml}$ and $55 \mathrm{U} / \mathrm{mg}$ were obtained, respectively (Malke and Ferretti, 1984). In this study, we found that $2000 \mathrm{U} / \mathrm{ml}$ of commercial native streptokinase gave the same activity as $1904 \mathrm{U} / \mathrm{ml}$ of our r-SK using an in vitro colorimetric model. Most of the in vitro methods that are currently applied to study thrombolysis have certain limitations. Some involve complex computational and mathematical skills that give only theoretical prediction of the outcome and most are expensive to be performed in a laboratory. The assay used in this study is easy and cost effective (Prasad et al., 2006).

The importance of substitution of expensive imported SK by locally produced low cost r-SK is reinforced by the notion that not all commercial SK preparations are effective (Quriel, 2002). This was demonstrated in a comparative study by Hermentin et al. (2005), in which they compared the activities of 16 different SK preparations and found that only three fulfilled the minimum requirements of the European Pharmacopoeia (Hermentin et al. 2005; Thimme, 2005).

\section{Conclusion}

This work introduces a novel strategy for the production of purified, efficient and low cost r-SK for pharmaceutical applications. The ongoing further step after the successful 
production of bioactive r-SK is to scale up the production process using fermentation technology. This would represent the first time to develop r-SK in Egypt.

\section{REFERENCES}

Albar JP, Corthals GL, Gil C, James P, Jensen ON, Palagi PM, Penque D (2007). Promoting proteomics knowledge in Europe: report on the activities of the EuPA Education Committee 2006-2007. Proteomics, 7Suppl1: 90-94.

Andreas EM (1990). Affinity chromatographic purification of streptokinase with monoclonal antibodies. Allerg. Immunol. (Leipz). 36(4): 277-285.

Azuaga Al, Dobson CM, Mateo PL, Conejero-Lara F (2002). Unfolding and aggregation during the thermal denaturation of streptokinase. Eur. J. Biochem. 269(16): 4121-4133.

Babashamsi M, Razavian MH, Nejadmoghaddam MR (2009). Production and purification of streptokinase by protected affinity chromatography. AJMB, 1(1): 47-51.

Balagurunathan B, Ramchandra NS, Jayaraman G (2008). Enhancement of stability of recombinant streptokinase by intracellular expression and single step purification by hydrophobic interaction chromatography. Biochem. Eng. J. 39: 84-90.

Banerjee A, Chisti Y, Banerjee UC (2004). Streptokinase-a clinically useful thrombolytic agent. Biotechnol. Adv. 22(4): 287-307.

Boersma E, Mercado N, Poldermans D, Gardien M, Vos J, Simoons Ml (2003). Acute myocardial Infarction. Lancet, 361(9360): 847-858.

Bradford M (1976). A rapid and sensitive method for the quantitation of microgram quantities of protein utilizing the principle of protein-dye binding. Anal. Biochem. 72: 248-254.

Castellino FJ, Sodetz JM, Brockway WJ, Siefring Jr. GE (1976). Streptokinase. Methods Enzymol. 45: 244-257.

Coleman RW, Marder VJ, Clawes AW, George JN, Goldhaber SZ (2005). Hemostasis and thrombosis: basic principles and clinical practice. Fifth edition, Lippincott Williams \& Wilkins, USA.

Frank C, Steiner K, Malke H (1995). Conservation of the organization of the streptokinase gene region among pathogenic streptococci. Med. Microbiol. Immunol. 184: 139-146.

Hermentin P, Cuesta-Linker T, Weisse J, Schmidt KH, Knorst M, Scheld M, Thimme M (2005). Comparative analysis of the activity and content of different streptokinase preparations. Eur. Heart J. 26: 933940.

Hoffman A, Roeder RG (1991). Purification of His-tagged proteins in nondenaturing conditions suggests a convenient method for protein interaction studies. Nucleic Acid Res. 19: 6337-6338.

Ignatova Z, Enfors SO, Hobbie M, Taruttis S, Vogt C, Kasche V (2000). The relative importance of intracellular proteolysis and transport on the yield of the periplasmic enzyme penicillin amidase in Escherichia coli. Enzyme Microb. Technol. 26: 165-170.

Innis MA, Gelfand DH, Sninsky JJ, White TJ (1990). PCR Protocols: A guide to methods and applications. San Diego, California: Academic Press. pp. 99-112.

Khil J, Im M, Heath A, Ringdahl U, Mundada L, Engleberg NC, Fay WP (2003). Plasminogen enhances virulence of group A streptococci by streptokinase-dependent and streptokinase-independent mechanisms. J. Infect. Dis. 188(4): 497-505.

Kim MR, Cheong YH, Chi WJ, Kang DK, Hong SK (2010). Heterologous production of streptokinase as a secretory form in Streptomyces lividans and nonsecretory form in Escherichia coli. J. Microbiol. Biotechnol. 20: 132-137.

Laemmli UK (1970). Cleavage of structural proteins during the assembly of the head of bacteriophage T4. Nature, 227(5259): 680685.

Larkin MA, Blackshields G, Brown NP, Chenna R, McGettigan PA, McWilliam $\mathrm{H}$, Valentin $\mathrm{F}$, Wallace IM, Wilm A , Lopez R, Thompson JD, Gibson TJ, Higgins DG (2007). Clustal W and Clustal X version 2.0. Bioinformatics, 23: 2947-2948.

Liu L, Sazonova IY, Turner RB, Chowdhry SA, Tsai J, Houng AK, Reed $\mathrm{GL}$ (2000). Leucine 42 in the fibronectin motif of streptokinase plays a critical role in fibrin-independent plasminogen activation. J. Biol. Chem. 275: 37686-37691.

Mahmoudi S, Abtahi H, Bahador A, Mosayebi G, Salmanian AH (2010). Production of recombinant streptokinase in $\mathrm{E}$. coli and reactivity with immunized mice. Pak. J. Biol. Sci. 13(8): 380-384.

Malke H, Ferretti JJ (1984). Streptokinase: cloning, expression, and excretion by Escherichia coli. Proc. Natl. Acad. Sci. USA. 81(11): 3557-3561.

Malke H, Steiner K, Gase K, Frank C (2000). Expression and regulation of the streptokinase gene. Methods, 21: 111-124.

Mao SJT, Tucci MA (1991). A colorimetric assay for measuring the lysis of a plasma clot. Anal. Biochem. 192: 6-10.

McCoy HE, Broder CC, Lottenberg R (1991). Streptokinase produced by pathogenic group C Streptococci demonstrate species-specific plasminogen activation. J. Infect. Dis. 164: 515-521.

Murray V, Norrving B, Sandercock PAG, Tere' A, Wardlaw JM, Wester $P$ (2010). The molecular basis of thrombolysis and its clinical application in stroke. J. Int. Med. 267(2): 191-208.

Perez N, Urrutia E, Camino J, Orta DR, Torres Y, Martinez Y (1998). Hydrophobic interaction chromatography applied to purification of recombinant streptokinase. Biotechnology, 10: 174-177.

Pimienta E, Ayala JC, Rodríguez C, Ramos A, Van ML, Vallín C, Anné $J$ (2007). Recombinant production of Streptococcus equisimilis streptokinase by Streptomyces lividans. Microb. Cell Fact. 5(6): p. 20.

Prasad S, Kashyp RS, Deopujari JY, Purohit HJ, Taori GM, Daginawala HF (2006). Development of an in vitro model to study clot lysis activity of thrombolytic drugs. BMC Thrombosis, 4: p. 14.

Pratap J, Rajamohan G, Dikshit KL (2000). Characteristics of glycosylated streptokinase secreted from Pichia pastoris: enhanced resistance of SK to proteolysis by glycosylation. Appl. Microbiol. Biotechnol. 53: 469-475.

Quriel K (2002). Safety and efficacy of various thrombolytic agents. Rev. Cardiovasc. Med. 3: s17.

Rodriguez P, Fuentes D, Munoz E, Rivero D, Orta D, Alburquerque S (1994). The streptokinase domain responsible for plasminogen binding. Fibrinolysis, 8: 276-285.

Sikri N, Bardia A (2007). A history of streptokinase use in acute myocardial infarction. Tex. Heart Inst. J. 34: 318-327.

Sriraman K, Jayaraman G (2006). Enhancement of recombinant streptokinase production in Lactococcus lactis by suppression of acid tolerance response. Appl. Microbiol. Biotechnol. 72: 1202-1209.

Sugimura K, Higashi N (1988). A novel outer-membrane-associated protease in Escherichia coli. J. Bacteriol. 170(8): 3650-3654.

Sun H, Ringdahl U, Homeister JW, Fay WP, Engleberg NC, Yang AY, Rozek LS, Wang X, Sjöbring U, Ginsburg D (2004). Plasminogen is a critical host pathogenicity factor for group A streptococcal infection. Science, 305(5688): 1283-1286.

Tamura K, Dudley J, Nei M, Kumar S (2007). MEGA4: Molecular evolutionary genetics analysis (MEGA) software version 4.0. Mol. Biol. Evol. 24: 1596-1599.

Thimme M (2005). Recombinant streptokinase: evidences from clinical use: reply. Eur. Heart J. 26: 1449-1450.

Thompson JD, Higgins DG, Gibson TJ (1994). CLUSTAL W : improving the sensitivity of progressive multiple sequence alignment through sequence weighing, position-specific gap penalties and weight matrix choice. Nucl. Acids Res. 22: 4673-4680.

Ward PN, Leigh JA (2004). Genetic analysis of Streptococcus uberis plasminogen activators. Indian J. Med. Res. 119: 136-140.

Wong SL, Ye RQ, Nathoo S (1994). Engineering and production of streptokinase in Bacillus subtilis expression-secretion system. Appl. Environ. Microbiol. 60: 517-523.

Yazdani SS, Mukherjee KJ (2002). Continuous culture studies on the stability and expression of recombinant streptokinase in Escherichia coli. Bioprocess Biosyst. Eng. 24: 341-346.

Zhang XW, Sun T, Huang XN, Liu X, Gu DX, Tang ZQ (1999). Recombinant streptokinase production by fed-batch cultivation of Escherichia coli. Enzyme Microb. Technol. 24: 647-650. 